\title{
Pengaruh Sanksi, Motivasi dan Tingkat Pendidikan terhadap Kepatuhan Wajib Pajak Orang Pribadi (Studi Kasus KPP Pratama Manado)
}

\author{
Oleh: \\ Evalin Yuanita Tologana
}

Fakultas Ekonomi dan Bisnis Pendidikan Profesi Akuntansi

Universitas Sam Ratulangi Manado

\begin{abstract}
This study aim to determine the effect of sanctions, motivation and level of education on tax compliance. Population in this study is the taxpayer listed in KPP Pratama Manado. Samples used were 100 taxpayer who are determine using a formula slovin. Data were analyzed using multiple linear regression followed by normality test, multicolinearity test, heterocedasticity test and autocorrelation test. The result showed the tax motivation sanctions and positive effect on tax compliance while education level had no effect on tax compliance.
\end{abstract}

Keywords: Tax Penalties, Tax Motivation, Level of Education and taxpayer compliance.

\section{PENDAHULUAN}

Pembangunan suatu negara akan berkembang dan berjalan dengan lancar jika berbagai sumberdaya dikelola dengan baik serta pendapatan nasional negara tersebut meningkat untuk membiayai semua pengeluaran termasuk pengeluaran pembangunan. Pendapatan nasional dapat diperoleh dari investasi, pajak, ekspor, impor, tingkat produksi masyarakat, tingkat konsumsi masyarakat, dll. Pajak adalah salah satu bagian terbesar dari penerimaan negara guna mencapai suatu pertumbuhan pembangunan yang diinginkan. Untuk menjalankan pembangunan negara tersebut pemerintah terus berusaha melakukan perbaikan-perbaikan dalam berbagai segi, salah satunya melalui reformasi perpajakan. Pemerintah akhir-akhir ini gencar melakukan berbagai upaya untuk meningkatkan penerimaan dari sektor pajak. Penentuan target penerimaan yang sangat tinggi dan selalu meningkat secara signifikan dari tahun ke tahun merupakan salah satu bukti, pajak merupakan primadona bagi sumber pendapatan negara.

Fakta di lapangan memaparkan bahwa tidak semua wajib pajak, patuh dan membayar pajak sesuai dengan ketentuan yang berlaku. Ada berbagai macam motif yang dilakukan oleh wajib pajak, dari keengganan dalam melaporkan harta riil yang mereka miliki, hingga sebatas keengganan mendatangi kantor pelayanan pajak dalam rangka pemenuhan kewajiban pelaporan perpajakan mereka. Tidaklah mudah untuk membebankan pajak pada masyarakat. Bila terlalu tinggi, masyarakat akan enggan membayar pajak. Namun bila terlalu rendah, maka pembangunan tidak akan berjalan karena dana yang kurang. Secara sederhana, tingkat kepatuhan wajib pajak tercermin dalam presentase penerimaan dan pelaporan pajak penghasilan tahunan (SPT Tahunan) Wajib Pajak Orang Pribadi

\section{TINJAUAN PUSTAKA}

Ada banyak pengertian mengenai pajak maupun perpajakan. Berikut akan dikemukakan pengertian pajak dan perpajakan menurut undang-undang dan para ahli. Menurut UU KUP Pasal 1 ayat (1),Pajak adalah kontribusi wajib kepada negara yang terutang oleh orang pribadi atau badan 
yang bersifat memaksa berdasarkan undang-undang dengan tidak mendapatkan imbalan secara langsung dan digunakan untuk keperluan negara bagi sebesar-besarnya kemakmuran rakyat. Menurut Soemitro, pajak adalah iuran rakyat kepada kas negara berdasarkan undang-undang (yang dapat dipaksakan) dengan tiada mendapat jasa timbal (kontraprestasi) yang langsung dapat ditunjukkan dan yang digunakan untuk membayar pengeluaran umum (Mardiasmo, 2011:1). Menurut Mardiasmo (2011:23) bahwa yang dimaksud Wajib Pajak (WP) adalah orang pribadi atau badan, meliputi pembayar pajak, pemotong pajak, dan pemungut pajak yang mempunyai hak dan kewajiban perpajakan sesuai dengan ketentuan peraturan perundang-undangan perpajakan. Wajib pajak juga didefinisikan sebagai orang pribadi yang menurut perundangundangan perpajakan ditentukan untuk melakukan kewajiban perpajakan, termasuk pemungut pajak atau pemotong pajak tertentu.Sesuai dengan self assessment, wajib pajak mempunyai kewajiban untuk mendaftarkan diri, melakukan sendiri perhitungan pembayaran dan pelaporan pajak terutangnya.

Pasal 2 ayat (1) UU No. 17 Tahun 2000 mengelompokkan subjek pajak sebagai

berikut:

1.Subjek pajak orang pribadi;

Orang pribadi sebagai subjek pajak dapat bertempat tinggal atau berada di indonesia.

2.Subjek pajak warisan yang belum terbagi sebagai satu kesatuan, menggantikan yang berhak; Warisan yang belum terbagi sebagai satu kesatuan merupakan subjek pajak pengganti, menggantikan yang berhak yaitu ahli waris.

3.Subjek Pajak badan;

Badan adalah sekumpulan orang dan atau modal yang merupakan kesatuan baik yang melakukan usaha maupun tidak melakukan usaha yang meliputi perseroan terbatas, perseroan komanditer, perseroan lainnya, Badan Usaha Milik Negara atau Daerah dengan nama dan dalam bentuk apapun, firma, kongsi, koperasi, dana pensiun, persekutuan, perkumpulan, yayasan, organisasi massa, organisasi sosial politik, atau organisasi yang sejenis, lembaga, bentuk usaha tetap dan bentuk badan lainnya termasuk reksadana.

4.Subjek Pajak Bentuk Usaha Tetap (BUT);

Badan Usaha Tetap (BUT) adalah bentuk usaha yang dipergunakan oleh orang pribadi yang bertempat tinggal di Indonesia atau berada di Indonesia tidak lebih dari 183 hari dalam jangka waktu 12 bulan, atau badan yang tidak didirikan dan tidak bertempat kedudukan di Indonesia, untuk menjalankan usaha atau melakukan kegiatan di Indonesia.

Menurut kamus besar bahasa Indonesia kata patuh berarti suka menurut; taat pada perintah, aturan. Dari definisi tersebut dapat diartikan bahwa kepatuhan berarti sifat patuh; ketaatan (Tim Penyusun Kamus Pusat Bahasa, 2002). Selanjutnya kepatuhan dalam hal perpajakan berarti suatu keadaan dimana wajib pajak memenuhi semua kewajiban perpajakan sesuai ketentuan-ketentuan atau aturan-aturan perpajakan yang diwajibkan menurut peraturan perundang- undangan perpajakan yang berlaku.Ada beberapa hal yang dapat mempengaruh kesadaran dan kepatuhan wajib pajak dalam memenuhi kewajiban pajaknya. Adapun faktor-faktor tersebut, antara lain:

1. Besaran tarif pajak.

2. Pelaksanaan penagihan yang rapi, konsisten dan konsekuen.

3. Ada tidaknya sanksi bagi pelanggar.

4. Pelaksanaan saksi secara konsisten, konsekuen dan tidak pandang bulu. Kepatuhan wajib pajak dalam memenuhi kewajiban perpajakannya pada dasarnya tercermin dari 3 (tiga) hal, yaitu: 
1. Pemenuhan kewajiban interim, seperti pembayaran masa dan Surat Pemberitahuan (SPT) Masa termasuk SPT PPN dan PPN BM yang dilaksanakan setiap bulan.

2. Pemenuhan kewajiban tahunan, seperti menghitung dan melunasi utang pajak, serta melaporkan perhitungan dan SPT diakhir tahun.

3. Pemenuhan ketentuan materil dan yuridis formal perpajakan melalui perlakuan pembukuan atas pengakuan penghasilan dan biaya serta berbagai transaksi keuangan lain untuk memperoleh dasar perhitungan pajak terutang yang tercermin dalam pembukuan wajib pajak.

\section{HIPOTESIS}

Pada hakikatnya, pengenaan sanksi perpajakan diberlakukan untuk menciptakan ketertiban dalam perpajakan yang mengarah pada kepatuhan wajib pajak dalam melaksanakan kewajiban perpajakannya. Dengan kata lain, sanksi perpajakan merupakan alat pencegah (preventif) agar wajib pajak tidak melanggar norma-norma pajak yang telah ditetapkan. Itulah sebabnya, penting bagi wajib pajak memahami sanksi-sanksi perpajakan sehingga mengetahui konsekuensi hukum dari apa yang dilakukan ataupun tidak dilakukan.

Penelitian yang dilakukan oleh Eka Maryati (2014) menemukan bahwa sanksi perpajakan berpengaruh positif terhadap kepatuha Wajib Pajak di Wilayah Kantor Pelayanan Pajak Pratama Bintan

\section{H1 : Diduga sanksi pajak berpengaruh terhadap kepatuhan wajib pajak}

Motivasi (motivation) adalah keinginan dalam diri seseorang yang

menyebabkan orang tersebut bertindak. Orang biasanya bertindak karena satu alasan, untuk mencapai tujuan.Jadi motivasi adalah sebuah dorongan yang diatur oleh tujuan dan jarang muncul dalam kekosongan. Kata-kata kebutuhan, keinginan, hasrat dan dorongan, semuanya serupa dengan motif, yang merupakan asal dari kata motivasi.

Dari beberapa artikel dan berita yang saya baca banyak masyarakat yang kurang antusias membayar pajak dikarenakan pajak dinilai memberatkan dan belum ada manfaat yang bisa di rasakan secara langsung. Proses dan mekanisme pembayaran pajak yang dinilai masih rumit menyebabkan tidak semua masyarakat mengetahui dengan jelas bagaimana cara menghitung dan mengisi SPT.Maraknya kasus penyelewengan pajak yang membuat masyarakat semakin ragu untuk mebayarkan uang mereka karena takut disalah gunakan oleh pihak-pihak tertentu. Lepas dari itu semua, hendaknya sebagai warga negara yang baik, terlebih bagi kita yang memperoleh pendidikan yang lebih baik menyikapi masalah tersebut dengan lebih bijak dan cerdas. Membayar pajak berarti kita turut berpartisipasi dalam pembangunan negara ke arah yang lebih baik. Tidak ada salahnya bagi kita untuk membayar pajak namun dengan cara yang cerdas.Membayar pajak dengan cerdas, maksudnya membuat perencanaan pajak untuk menekan biaya pajak sekecil mungkin tapi tidak melanggar peraturan yang ada dengan memanfaatkan celah dari peraturan tersebut. Bagi masyarakat yang kurang mengerti bagaimana cara menghitung dan mengisi SPT atau melakukan Tax planning makasesuai dengan UU Perpajakan dapat menggunakan jasa seorang konsultan pajak atau badan yang berhubungan dengan masalah tersebut untuk mempermudah menghitung dan melaporkan kewajiban membayar pajaknya. Selain itu hendaknya pemerintah lebih transparan lagi dalam pengelolaan pajak dan menindak tegas para aparat pajak yang melakukan penyelewengan agar masyarakat yakin dan percaya untuk membayar pajak.

\section{H2 : Diduga motivasi pajak berpengaruh terhadap kepatuhan wajib pajak}


Pendidikan berasal dari kata "didik", lalu kata ini mendapat awalan -me sehingga menjadi "mendidik", artinya memelihara dan memberi latihan. Dalam Kamus Besar Bahasa Indonesia, pendidikan adalah proses pengubahan sikap dan tata laku seseorang atau kelompok orang untuk dalam usaha mendewasakan manusia melalui upaya pengajaran dan pelatihan. Dalam pengertian luas, pendidikan dapat diartikan sebagai sebuah proses dengan metode-metode tertentu sehingga orang meperoleh pengetahuan, pemahaman, dan cara bertingkah laku yang sesuai dengan kebutuhan. Menurut Tardif, dalam pengertian yang luas dan representatif, pendidikan adalah seluruh tahapan pengembangan kemampuan- kemampuan dan perilaku-perilaku manusia, juga proses penggunaan hampir seluruh pengalaman kehidupan (Dalam Syah, 2010:10).

\section{H3 : Diduga tingkat pendidikan berpengaruh terhadap kepatuhan wajib pajak}

Pengaruh sanksi pajak, motivasi, dan tingkat pendidikan secara simultan terhadap kepatuhan wajib pajak di KPP Pratama Manado.

H4 : Diduga sanksi pajak, motivasi dan tingkat pendidikan berpengaruh terhadap kepatuhan wajib pajak di Kantor Pelayanan Pajak di KPP Pratama Manado.

\section{HASIL ANALISIS DAN PEMBAHASAN}

\subsection{Hasil Analisis}

Sebagian besar responden yang mengisi kuesioner memiliki pendidikan non perguruan tinggi yang berjumlah 38 orang dengan persentase $38 \%$. Kemudian di tingkat perguruan tinggi terdapat 62 orang dengan persentase $62 \%$. Data ini terdiri dari 52 orang laki-laki dan 48 orang perempuan.dari segi pekerjaan data responden tersebut terbagi atas 37 Pegawai Negeri Sipil, 32 pegawai swasta, 5 profesional,20 wiraswasta dan 6 lainnya.

Dari kuesioner yang telah dikembalikan oleh responden yaitu sebanyak 100 orang atau 100 wajib pajak orang pribadi, dimana yang mengisi kuesioner yaitu mereka yang telah memiliki nomor pokok wajib pajak dengan berbagai latar belakang profesi. Maka, data yang didapat dari hasil jawaban responden ditabulasikan ke dalam tabel sesuai dengan klasifikasinya.

Untuk variabel sanksi digunakan 5 pertanyaan. Selanjutnya pada variabel motivasi digunakan 5 pertanyaan, Selanjutnya variabel tingkat pendidikan di ukur berdasarkan tingkat pendidikan dasar sampai jenjang perguruan tinggi strata 3 yang kemudian akan ditabulasi dalam kategori perguruan tinggi dan non perguruan tinggi.Pada variabel kepatuhan wajib pajak orang pribadi juga digunakan 5 pertanyaan. 
Tabel 4.1 Tabel Hasil Validitas Correlations

\begin{tabular}{|c|c|c|c|c|c|}
\hline & & Sanksi & Motivasi & $\begin{array}{l}\text { Kepatuhan_- } \\
\text { Wajib_Pajak }\end{array}$ & $\begin{array}{c}\text { Tingkat } \\
\text { Pendidikan }\end{array}$ \\
\hline \multirow{3}{*}{$\begin{array}{l}\text { Sanksi } \\
\text { Correlation }\end{array}$} & Pearson & 1 &, $326 * *$ &, $729 * *$ & , 074 \\
\hline & & & , 000 & , 000 & ,231 \\
\hline & Sig. (1- & 100 & 100 & 100 & 100 \\
\hline \multirow{3}{*}{$\begin{array}{l}\text { Motivasi } \\
\text { Correlation }\end{array}$} & Pearson &, $326 * *$ & 1 &, $846 * *$ & ,057 \\
\hline & & ,000 & &, 000 & ,287 \\
\hline & Sig. (1- & 100 & 100 & 100 & 100 \\
\hline \multirow{3}{*}{$\begin{array}{l}\text { Kepatuhan_WP } \\
\text { Correlation }\end{array}$} & Pearson &, $729 * *$ &, $846 * *$ & 1 & 106 \\
\hline & & 000 & 000 & & 147 \\
\hline & Sig. (1- & 100 & 100 & 100 & 100 \\
\hline \multirow{3}{*}{$\begin{array}{l}\text { Tingkat Pend } \\
\text { Correlation }\end{array}$} & Pearson &, 074 &, 057 & , 106 & 1 \\
\hline & & ,231 & ,287 & 147 & \\
\hline & Sig. (1- & 100 & 100 & 100 & 100 \\
\hline
\end{tabular}

**. Correlation is significant at the 0.01 level (1-tailed).

Sumber: Data Olahan, 2015

\section{Uji Validitas}

Uji validitas dimaksudkan untuk mengukur sah atau valid tidaknya suatu kuesioner. Suatu kuesioner dikatakan valid apabila pertanyaan pada kuesioner mampu mengungkapkan sesuatu yang tidak diketahui.Suatu indikator pernyataan dikatakan valid apabila korelasi Antara masing-masing indikator menunjukkan hasil yang signifikan.

Berdasarkan keseluruhan hasil yang ada di tabel 4.3, disimpulkan bahwa hampir semua hubungan variabel yang ada di dalam penelitian ini valid. Dapat dilihat berdasarkan nilai korelasi dari hubungan antara sanksi dengan motivasi sebesar 0.326 , hubungan antara sanksi dan tingkat pendidikan sebesar 0.074 , hubungan sanksi dan kepatuhan wajib pajak sebesar 0.729 dan hubungan antara motivasi dengan kepatuhan wajib pajak sebesar 0.846 dimana nilai-nilai tersebut lebih besar dari 0,01 .

\section{Uji Normalitas}

Salah satu cara yang digunakan untuk menguji apakah distribusi data normal atau tidak adalah dengan dengan melihat normal probability plot yang membandingkan distribusi kumulatif dari data sesungguhnya dengan distribusi kumulatif dari distribusi normal. Distribusi normal akan membentuk satu garis lurus diagonal dan ploting data akan dibandingkan dengan garis diagonal. Jika distribusi data normal, maka garis yang menggambarkan data sesungguhnya akan mengikuti garis diagonalnya. Berdasarkan hasil pengujian SPSS 22, normal probability plot yang terbentuk, data menyebar di sekitar garis diagonal dan mengikuti arah garis diagonal, dengan demikian maka dapat dikatakan bahwa distribusi data dalam penelitian ini residual normal. 


\section{Gambar 4.1}

Hasil Uji Normalitas

Normal P-P Plot of Regression Standardized Residual

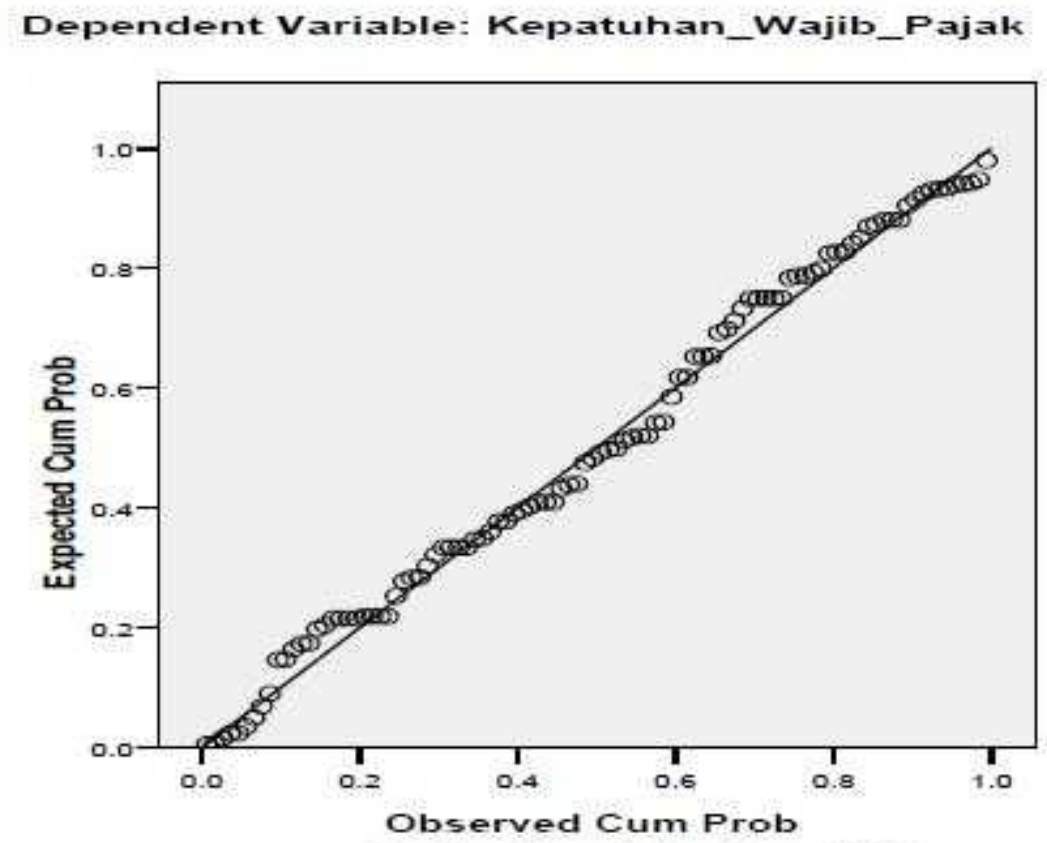

Sumber: Pengolahan Data SPSS

\section{Multikolinearitas}

Suatu model regresi yang baik seharusnya bebas dari masalah multikolinearitas dan tidak terdapat korelasi antar variabel independen.Hal ini dapat diketahui melalui besarnya nilai VIF dan tolerance. Jika nilai VIF $<10$ dan tolerance $<1$ maka model regresi bebas multikolinearitas.Dengan demikian, asumsi multikolinearitasi terpenuhi (bebas dari multikolinearitas). Hasil uji multikolinearitas pada penelitian ini ditunjukkan oleh tabel 4.4 berikut. 
Tabel 4.2 Hasil Uji Multikolinearitas dan Autokorelasi

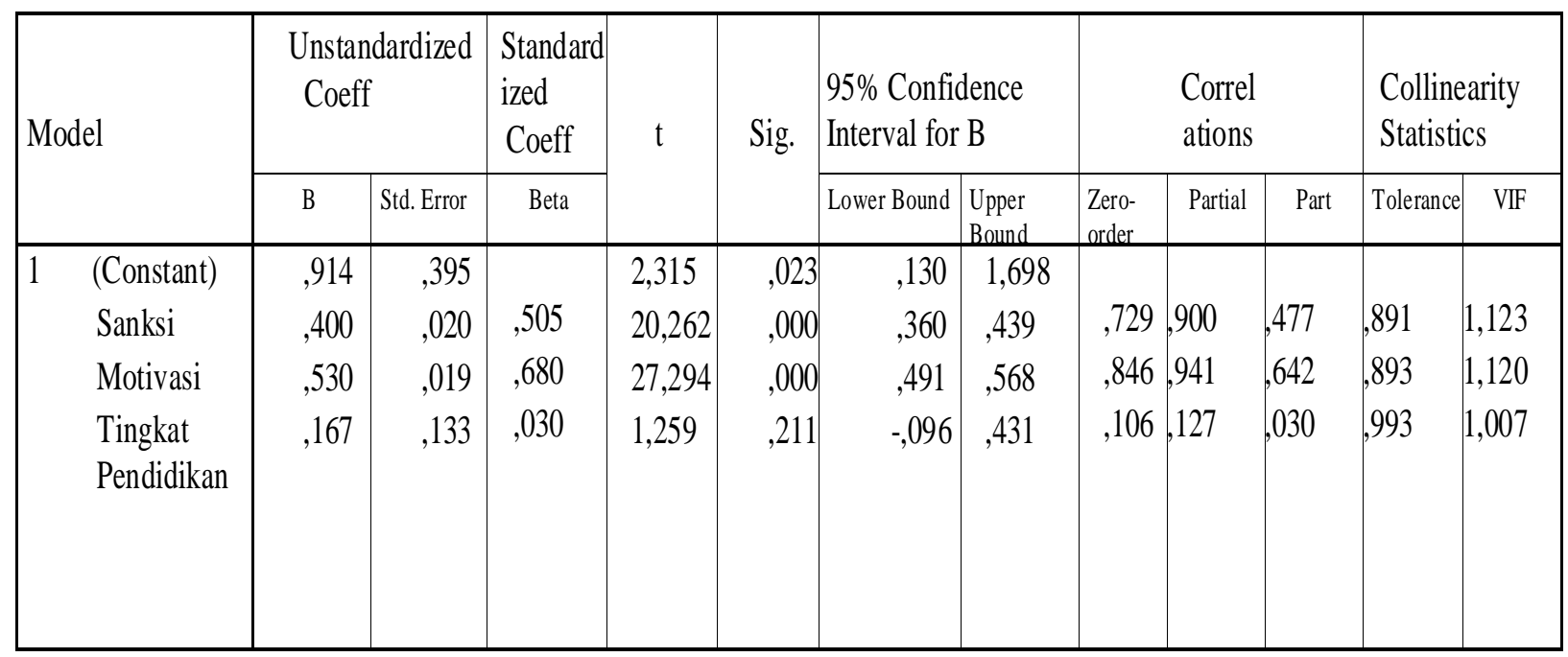

Berdasarkan hasil olah data pada tabel 4.2 Diperoleh nilai VIF ketiga variabel independen berada di bawah nilai 10 . Ini berarti bahwa tidak terdapat multikolinearitas pada variabel independen.

\section{Uji Heterokedastisitas}

Hasil uji heteroskedastisitas menunjukkan bahwa grafik scaterplot tidak membentuk pola yang teratur seperti bergelombang, melebar ataupun menyempit, tetapi menyebar di atas maupun di bawah nilai nol pada sumbu Y sehingga dapat disimpulkan model regresi tidak mengandung heteroskedastisitas.

Gambar 4.2 Uji Asumsi Klasik Heteroskedastisitas

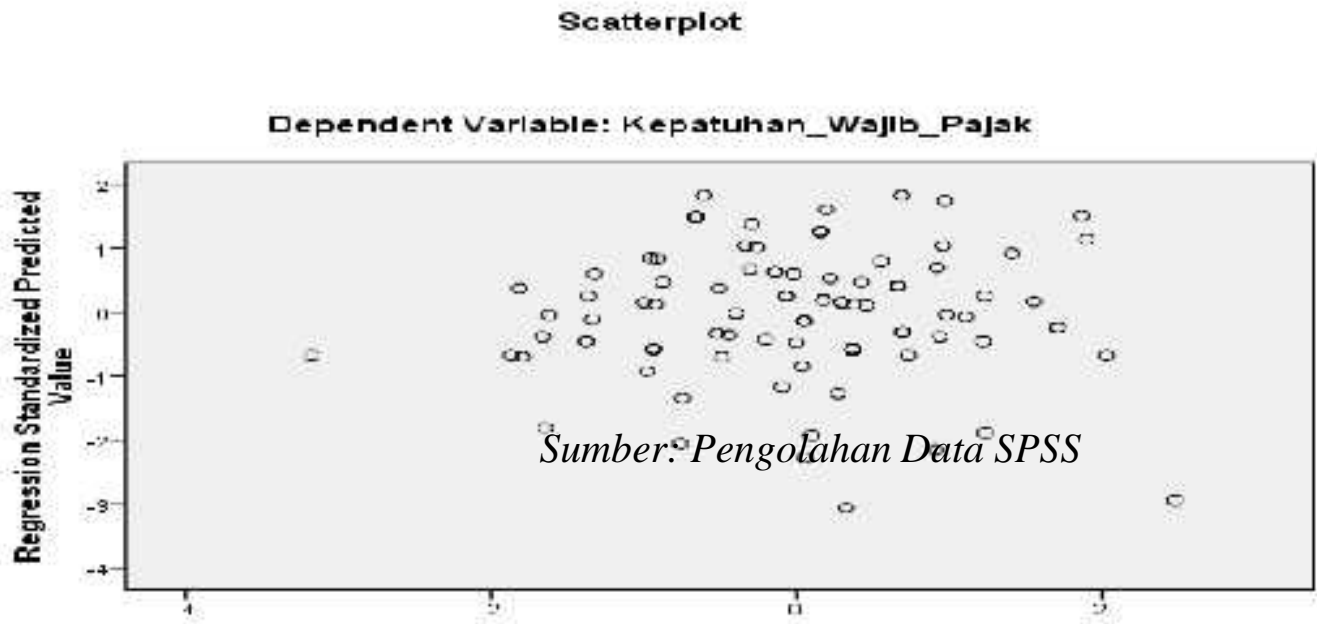

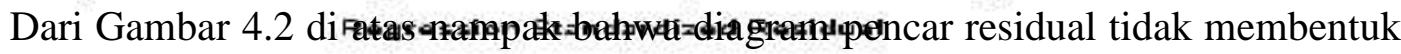
suatu pola tertentu tetapi menyebar secara acak sehingga dapat disimpulkan bahwa model regresi terbebas dari heteroskedastisitas. 


\section{Hasil Analisis Berganda}

Tabel 4.3 Hasil Coefficients Penelitian

\section{Coefficients ${ }^{\mathrm{a}}$}

\begin{tabular}{|c|c|c|c|c|c|}
\hline \multirow{2}{*}{ Model } & \multicolumn{2}{|c|}{$\begin{array}{l}\text { Unstandardized } \\
\text { Coefficients }\end{array}$} & \multirow{2}{*}{$\begin{array}{c}\text { Standardized } \\
\text { Coefficients } \\
\text { Beta }\end{array}$} & \multirow{2}{*}{$\mathrm{t}$} & \multirow{2}{*}{ Sig. } \\
\hline & B & $\begin{array}{l}\text { Std. } \\
\text { Error }\end{array}$ & & & \\
\hline \multirow{4}{*}{$\begin{array}{c}\text { 1(Constant) Sanksi Motivasi } \\
\text { T ingkat Pendidikan }\end{array}$} & ,914 & ,395 & & 2,315 &, 023 \\
\hline & ,400 & ,020 &, 505 & 20,262 &, 000 \\
\hline &, 530 & ,019 & ,680 & 27,294 &, 000 \\
\hline &, 167 &, 133 &, 030 & 1,259 &, 211 \\
\hline
\end{tabular}

a. Dependent Variable: Kepatuhan_Wajib_Pajak Sumber: Olahan data

Dari tabel 4.5 didapatkan persamaan untuk semua variabel yang dianalisa adalah $\mathrm{Y}=0,914+0.400 \mathrm{X} 1+0,530 \mathrm{X}_{2}+0.167 \mathrm{D}$, dengan penjabaran sebagai berikut.

1. Nilai konstan sebesar 0,914 . Hal ini berarti jika nilai sanksi, motivasi dan tingkat pendidikan konstan atau sama dengan 0 maka besarnya tingkat kepatuhan wajib pajak (Y) adalah sebesar nilai konstan yaitu 0,914 .

2. Peningkatan 1 satuan pada variabel sanksi (X1) akan meningkatkan kepatuhan wajib pajak sebesar 0,400. Sebaliknya, penurunan 1 satuan atas variabel sanksi (X1) akan menurunkan tingkat kepatuhan wajib pajak sebesar nilai yang sama .

3. Peningkatan 1 satuan atas variabel motivasi (X2) akan meningkatkan kepatuhan wajib pajak sebesar 0,530. Sebaliknya, penurunan 1 satuan atas variabel motivasi (X2) akan membuat kepatuhan wajib pajak menurun dengan nilai yang sama.

4. Peningkatan 1 satuan atas tingkat pendidikan (D) akan meningkatkan kepatuhan wajib pajak sebesar 0,167 dan penurunan 1 satuan pada tingkat pendidikan akan membuat penurunan atas kepatuhan wajib pajak sebesar 0.167 . 


\section{Uji Determinasi}

Tabel 4.4 Tabel Hasil Model Summary

\section{Model Summaryb}

\begin{tabular}{|c|c|c|c|c|c|c|c|c|c|c|}
\hline \multirow{2}{*}{ Model } & \multirow{2}{*}{$\mathrm{R}$} & \multirow{2}{*}{$\begin{array}{l}\mathrm{R} \\
\text { Square }\end{array}$} & \multirow{2}{*}{$\begin{array}{l}\text { Adjusted } \\
\text { R Square }\end{array}$} & \multirow{2}{*}{$\begin{array}{l}\text { Std. } \\
\text { Error of } \\
\text { the } \\
\text { Estimate }\end{array}$} & \multicolumn{5}{|c|}{$\begin{array}{l}\text { Change } \\
\text { Statistics }\end{array}$} & \multirow{2}{*}{$\begin{array}{l}\text { Dur } \\
\text { bin- } \\
\text { Wat } \\
\text { son }\end{array}$} \\
\hline & & & & & \begin{tabular}{|l}
$\mathrm{R}$ \\
$\mathrm{Squ}$ \\
are \\
$\mathrm{Ch}$ \\
ang \\
$\mathrm{e}$
\end{tabular} & $\begin{array}{l}\mathrm{F} \\
\text { Change }\end{array}$ & df1 & df 2 & $\begin{array}{l}\text { Sig. } \\
\text { F } \\
\text { Cha } \\
\text { nge }\end{array}$ & \\
\hline 1 &, $973^{a}$ & 947 & ,945 &, 64329 &, 947 & 569,960 & 3 & 96 &, 000 & 2,145 \\
\hline
\end{tabular}

a. Predictors: (Constant), Tingkat Pendidikan, Motivasi, Sanksi

b. Dependent Variable: Kepatuhan_Wajib_Pajak Sumber: Olahan data SPSS

Dari tabel 4.7, dapat disimpulkan bahwa hubungan di antara sanksi (X1), motivasi (X2) dan tingkat pendidikan (D) dengan kepatuhan Wajib Pajak (Y) sangatlah kuat, yang mana hasil tersebut didasarkan pada nilai $\mathrm{R}$ (Coefficient) sebesar 0,973 dengan kata lain nilai ini mendekati 1 sebagaimana syarat nilai koefisien dalam penelitian ini. Selanjutnya, hasil pada tabel yang sama dapat disimpulkan bahwa ketiga variabel tersebut, yaitu sanksi (X1), motivasi (X2) dan tingkat pendidikan, mempunyai peranan penting sebesar 0,945 atau $94,5 \%$ terhadap peningkatan atau penurunan kepatuhan wajib pajak $(Y)$ dan $5,5 \%$ sisanya $(=0,55)$ disebabkan oleh faktor-faktor lain yang tidak dianalisa di dalam penelitian ini.

\section{KESIMPULAN} berikut:

Dari hasil penelitian, analisa data dan pembahasan, maka dapat diambil kesimpulan sebagai

1.Bahwa sanksi memiliki pengaruh positif signifikan terhadap kepatuhan wajib pajak pada KPP Pratama Manado. Hal ini terjadi karena masyarakat lebih terdorong untuk patuh oleh karena adanya sanksi itu sendiri yang dianggap merugikan mereka jika melakukan pelanggaran perpajakan.

2.Bahwa motivasi memiliki pengaruh positif signifikan terhadap kepatuhan wajib pajak pada KPP Pratama Manado.Hal ini terjadi oleh karena adanya kesadaran wajib pajak di kota manado terhadap kewajiban perpajakan serta fungsi pajak itu sendiri yang mungkin dianggap turut memberi keuntungan. 
3.Bahwa secara parsial tingkat pendidikan tidak memiliki pengaruh signifikan terhadap kepatuhan wajib pajak pada KPP Pratama Manado. Ini berarti tinggi rendahnya pendidikan wajib pajak tidak menjamin seorang wajib pajak untuk patuh terhadap ketentuan perpajakan.

4.Besarnya pengaruh secara bersama-sama antara variabel sanksi, motivasi dan tingkat pendidikan dengan kepatuhan wajib pajak pada KPP Pratama Manado sangat kuat dengan nilai FHitung sebesar 569,960

Saran yang dikemukakan adalah sebagai berikut:

1.Penelitian selanjutnya dapat menambah sampel penelitian dengan ruang lingkup yang lebih besar agar hasilnya lebih baik.

2.Penelitian selanjutnya dapat menambah variabel independen lain atau mengganti variabel independen berdasarkan teori-teori yang ada.

3.Bagi Kantor Pelayanan Pajak Pratama Manado diharapkan mampu melaksanakan penegakan sanksi pajak sesuai dengan peraturan perpajakan yang berlaku untuk meningkatkan kepatuhan wajib pajak dalam memenuhi kewajiban perpajakannya.Selanjutnya dapat lebih giat melakukan sosialisasi perpajakan kepada seluruh lapisan masyarakat agar masyarakat lebih termotivasi untuk mematuhi ketentuan-ketentuan perpajakan yang berlaku.

\section{DAFTAR PUSTAKA}

Dianawati, Susi. (2008). Analisis Pengaruh Motivasi dan Tingkat Pendidikan terhadap Kepatuhan Wajib Pajak (Studi Kasus pada KPP Pratama Jakarta Tanah Abang Satu). Skripsi Akuntansi Universitas Islam Negeri Syarif Hidayatullah Jakarta.

Eka Maryati. (2014). Pengaruh sanksi pajak, motivasi dan tingkat pendidikan terhadap kepatuhan wajib pajak (studi pada wilayah kantor prlayanan pajak pratama bintan). Skripsi Akuntansi Universitas Maritim Raja Ali Haji Tanjung pinang

Harjanti Puspa Arum. (2012). Pengaruh kesadaran wajib pajak, pelayanan fiskus, dan sanksi pajak terhadap kepatuhan wajib pajak orang pribadi yang melakukan kegiatan usaha dan pekerjaan bebas (studi di wilayah kpp pratama cilacap). Skripsi Akuntansi Universitas Diponegoro .Semarang .

Kurniawan, Albert. (2009). Belajar Mudah SPSS untuk Pemula. Yogyakarta: Media Kom.

Mardiasmo. 2011. Perpajakan. Edisi Revisi. Yokyakarta: Andi.

Muliari, Ni Ketut dan Putu Ery Setiawan. (2010). Pengaruh Persepsi tentang Sanksi Perpajakan dan Kesadaran Wajib Pajak pada Kepatuhan Pelaporan Wajib Pajak Orang Pribadi di Kantor Pelayanan Pajak Pratama Denpasar Timur. Universitas Udayana. Denpasar.

Mulyono, Djoko. 2008. Ketentuan Umum Perpajakan. Yogyakarta: Andi. Supriyati. (2012).

Dampak Motivasi dan Pengetahuan Perpajakan Terhadap Kepatuhan Wajib Pajak.

Jurnal Investasi. Vol. 8. No. 1.

Syahri, Ahmad. (2010). Analisis Pengaruh Motivasi dan Tingkat Pendidikan.

Skripsi Akuntansi Perpajakan Universitas Islam Negeri Syarif Hidayatullah Jakarta. Silalahi, Ulber. (2006). Metode Penelitian Sosial. Bandung: Unpar Press.

Resmi,Siti. (2009). Perpajakan : Teori dan Kasus.Yogyakarta:Salemba empat.

Undang-Undang Republik Indonesia No.20 Tahun 2003 tentang Sistem Pendidikan Nasional.

Undang-Undang Republik Indonesia No.16 Tahun 2009 tentang Ketentuan Umum dan Tata Cara Perpajakan 
Wiratna,sujarweni.2014. SPSS Untuk Penellitian. Yogyakarta : Pustaka Baru Press.

Yudiatmaja,Fridayana.(2013).Analisis regresi dengn menggunakan aplikasi computer statistik SPSS. Jakarta : PT.Gramedia Pustaka Utama.

------- 2002.Kamus Besar Bahasa Indonesia (Edisi Ketiga). Jakarta : Balai Pustaka www.fiskaldepkeu.go.id

www.pajak.go.id

www. kemenkeu.go 